\title{
The Image of Vietnam as a Tourism Destination for Malaysian Tourists
}

\author{
Dang Hong Loi $^{1} \&$ Ilham Sentosa ${ }^{1}$ \\ ${ }^{1}$ City University College of Science and Technology, Malaysia \\ Correspondence: Dang Hong Loi, City University College of Science and Technology, Malaysia. E-mail: \\ may.dang@yahoo.com
}

Received: October 28, 2014

Accepted: December 9, $2014 \quad$ Online Published: December 20, 2014

doi:10.5539/ijbm.v10n1p258

URL: http://dx.doi.org/10.5539/ijbm.v10n1p258

\begin{abstract}
The main objective of this study is to finding the images of Vietnam tourism destination perceived by Malaysian tourists. The study based on replies to 599 questionnaires and the secondary data. The Structure Equation Modelling was employed to identify the relationship among the variables. The result of Confirmation Factor Analysis (CFA) shows the beneficiary images of Vietnam including of "interesting history and rich culture" "delicious cuisines and friendliness". The negative images in Vietnam consists of poor transportation, poor infrastructure and cleanliness problems that challenges to tourism Vietnam destination. The study may be interesting to destination marketers, Vietnam Government and Travel Companies, especially for those developing destinations which intend to differentiate themselves from others country.
\end{abstract}

Keywords: tourism, destination, image, marketing, perception, SEM, Vietnam

\section{Introduction}

Tourism is one of the growing factor that contributing tremendously to the economic development of the world (Salleh et al, .2013; Haque \& Khan 2013; Mohamed et al., 2013; Salomao et al., 2013). Regardless of today's economic recession but travelling services and tourism industry have not stopped and are still growing gradually. It plays a key role in fostering the global economic growth and brings about developments of other sectors such as infrastructure, investment, transport, services and so on. World tourism has been increased $6.6 \%$ in 2010 from 851 to 940 million and also receipts US\$919 billion increased in 2010 (UNWTO, 2011).

According to The Vietnam Tourism Statistic, over the past of ten years Vietnam has seen an extraordinary growth in tourist numbers from the year of 1998 until recent years (Vietnam Travel, 2009). By the year of 2020, Vietnam will attract about 4.5 to 5 million foreigner visitors (Vietnamnet, 2013). Although always in an increasing trend, Vietnam is still far behind compared to Malaysia, Thailand and Singapore in attracting foreign tourists (Le 2010; ASEAN Secretariat, 2008). This is due to Vietnam tourism destination marketing is still weak and only base on subjective experiences (Le, 2010). According to Le (2010, p. 3), "Vietnam has not been study on any images of Vietnam as a tourism destination in foreigner markets". Mr. Vu The Binh, Chairman of the Vietnam Tourism Association pointed out that building Vietnam as a tourism image or brand was important to the Vietnam tourism industry. Although there were many promotions, marketed destination and site as well as developed infrastructure have been introduced, but have yet to consistently present the tourism of Vietnam to international travelers. In the context, the problem seemed to be mostly with image and communication. Therefore, Vietnam have to better develop its tourism products, especially on images of the tourism (Binh, 2013).

In Vietnam, Malaysian tourists are regarded as one of the target markets and Vietnam's tourism industry has achieved initial success in attracting Malaysian travelers. According to the Vietnam National Administration of Tourism (2014), Malaysian is among top ten international visitors in Vietnam, Malaysia visitors is in queue number eight after Australia in the year of 2011 and 2012. However, the number of Malaysian tourists' visited Vietnam has been increasing and eventually over took Australia in the year of 2013 and ranked at number seven. In fact, the number of Malaysian tourists visiting Vietnam has increased gradually from 2000 to 2013, hitting a peak of nearly 340,000 in 2013 (VNAT, 2014). Therefore, it is crucial to identify the image of Vietnam's tourism according to customer behaviour in order to improve marketing tactics properly.

Establishing an image for Vietnam that distinguishes it from its neighbors is at the heart of its marketing strategy. 
The overall of image destination can be enhanced if tourists return on investment and service superiority are conducted through experiential value perspective of Malaysian tourists perception. Therefore, this research aimed to determine and analyze the image destination of Vietnam among Malaysian travelers.

\section{Literature Review}

Each destination has an own image, but some can have stronger image than other, which is an important factor to affect the demand. The concept of destination image has become a strategic weapon and competitive advantages in tourism marketing. Thereby, the destination marketer has to evaluate the strengths and weaknesses of destination, as it is important to influence tourists' travel motivation and decision making process (O'Leary \& Deegan, 2003). Beyond doubt, a positive image of a destination will create a positive thinking and decision making towards to a destination. Whether it right or wrong, true or false, real or imagined, image will shape and guide behaviour (Hasan \& Gulcin, 2013). The definition of destination image is complex and problematic because it is based on subjective beliefs and feeling (Lin and Huang, 2009; Salem, 2009; Castro et al., 2007; Grosspietsch, 2006; Jenkins, 1999), there are few image studies on image destination have been sought to fully examine and understand its complex characteristics (Salem, 2009). According to (Echtner \& Ritchie, 2003), there are many researchers in tourism field have made recurrent use of the term "destination image" but a precise definition to it is often avoided.

In 1993 and 2003, Echtner and Ritchie identified the components of destination image which could be considered in terms of attribute-holistic, functional-psychological and comment-unique. These components were adopted by many researchers in tourism research so far (Le, 2010; Salem, 2009; Mao, 2008; Stepchenkova \& Morrison, 2006, 2008; Govers et al., 2007; Tacsi \& Gartner, 2007; Prebensen, 2007; Vaughan, 2007; Baloglu \& Mangaloglu, 1999a; Vaughan \& Edwards, 1999; Milman \& Pizam, 1995). There are a rising number of marketing challenges and one of the most significant is the need for an effective destination positioning in strategy.

In building a strong destination brand, importance is likely to be attached to image creation and destination differentiation. Reynolds (1965) described the formation of destination image as the development mental construct based on few impressions chosen from variety of information such as promotional literature (travel brochures, posters), the opinion from others (family/friends, travel agents) and general media (newspapers, magazines, television, books and movies). Different people have different unique image of a particular destination, which comprises their own memories, associations and imaginations of a particular destination (Jenkins, 1999; Jenkins \& McArthur, 1996). In 1972, Gunn was amongst the first of researchers to identify how the cognitive of images are formed, followed by few other researchers investigated the images formation process as well as measurement and employed three-stages from Gunn (1972) which the most recent study adopted by Salem (2009). The process starts with image perceived as organic image, which the image is based primarily upon information assimilated from non-touristic and non-commercial sources such as words of mouths, general media (books and magazines) and education. The next step is induce image, which more commercial sources such as advertising and other promotional tools are used. Finally, modifying the image take place, where the tourists modify their image perceived based on actual experiences. Gunn's theory and Echtner and Ritchie's concept offered a conceptual framework on image formation and perceived, which explained in the conceptual framework of Vietnam as a tourism destination for Malaysian travelers of this research.

\section{Conceptual Framework}

This research developed a conceptual research model based on the component of destination image of Etchner and Ritchie (2003) and image formation process (Gunn, 1972) theories approach. As Gunn's theory came across as a unique in the formation of destination images, marketing or information sources in tourism industry is vary among historical, economic, political, media or even social sources, which implies silent consent a strong link between a country's image and its national image (Stepchenkova \& Eales, 2010). The components of destination image developed by Echtner and Ritchie (1993 and 2003) comprised of all components of destination images such as attribute, holistic, functional, psychological, common and unique. Therefore, the hypothesis of this study were developed through this theory and concept. 


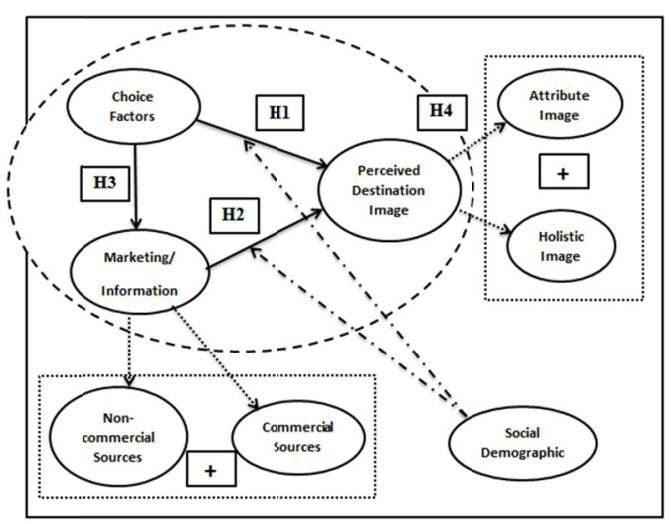

Figure 1. The conceptual framework of Vietnam's image as a tourism destination for Malaysian

Source: Developed for this Research.

The major features from the theories for this research framework has threefold. Firstly, the conceptual of the components of destination image and the theory of destination image formation which can be a strong base to evaluate the situation of tourism destination image of Vietnam as a tourism destination for Malaysian travelers. Secondly, it covers all the most important aspects of tourism destination image. Thirdly, this theory and concept focuses on specific aspects of the more comprehensive theory of tourism destination image. Although others measurement of tourism destination image such as the effects of media and socio-demographic are not termed as "theory" or "concept" but they can be still considered as part of tourism destination image due to it is a procedure and system of rules to assumption that can suggest methods to identify the image of Vietnam as a tourism destination for Malaysian travelers.

\section{Methodology}

In this study, the researcher adopted mainly quantitative methodology and partly qualitative approach which is line with the researches by Reilly (1990) and Dann (1996). The research process involved in this study comprised of two phases, which are as presented in Figure 2. The first phase was a preliminary phase which involved qualitative support in nature to identify the general images of Vietnam and to develop a list of image attributes for Malaysian tourism market. In addition, open-ended questions of the pre-test and pilot tested survey were used as a tool to identify the potential attributes. Eventually, the final list of attributes was compiled from the various sources i.e. literature review that is relevant to Vietnam about destination images, Malaysia tour operators' image, brochure and the free elicitation of the three holistic images of Vietnam during the pre-tested and pilot testing.

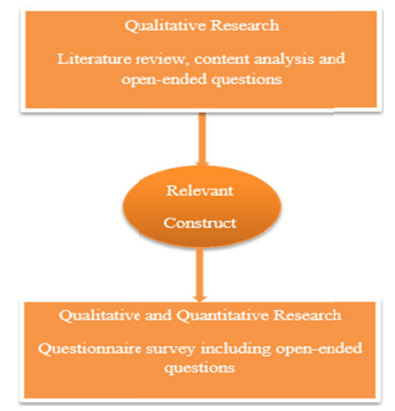

Figure 2. Methodology for Vietnam's tourism destination image research

Source: Adapted from Jenkins (1999).

The second phase was a combination of qualitative and quantitative approaches which consisted of open-ended and scale questions respectively. Simple Random Sampling technique was used to select sample and sample size. The questionnaire on respondents' perceived Vietnam as a tourist destination for Malaysian travelers was modified based on the list of attributes was developed by Echtner and Ritchie's (1991, 1993, 2003, p. 45) to 
measure the attribute based components of tourism destination image. The characteristics in the category of Malaysian tourists perceived included hotels, cuisines, transportation, beach, attractions, and people's friendliness. Respondents were asked to indicate their level of agreement based on a Likert type scale of 1 to 5 (from very unimportant to very important) and (strongly disagree to strongly agree).

All the questionnaire were categorized and scaled after collection and entered into Statistic Package for the Social Sciences Software (SPSS) with version 20 in order to process statistical data followed by a confirmatory factor analysis (CFA) in the approach of structural equation model (SEM). The CFA and SEM procedures were conducted utilizing AMOS software.

\section{Findings}

Out of a total 599 respondents listed for analysis, a large number of respondents were male (60\%) with majority of age group between 20-59 represented $94 \%$ of the total respondents. There were a large number of Chinese $(62 \%)$ followed by Malay $(20 \%)$ and Indian ( $8 \%)$. Over $80 \%$ of the whole sample completed tertiary education (diploma, bachelor, master or doctorate) followed by secondary (15\%) and primary school (2\%). More than $30 \%$ of respondents were employees (company employees), researcher/lecturer/teachers (19\%), self-employed (19\%), and $16 \%$ is travel agent.

Confirmatory factor analysis (CFA) and structural equation modelling (SEM) were applied to the data set to test the conceptual framework model as well as examine the relationship between each pairs of variables as suggested in the hypothesis. According to Nunnally and Bernstein (1994), a reliability analysis of Cronbach's alpha value 0.7 or more are considered to be accepted good indication of reliability. The resulting Cronbach's alpha values of the reliability test performed on Vietnam destination image is 0.73 , thus, the internal consistency of Vietnam as a tourist's destination for Malaysian travelers is acceptable.

SEM is a statistical technique that combines factors analysis, regression analysis, and path analysis (Bollen 1989). It was adopted in this study as it is able to evaluate the direction and significant of the relationships between endogenous variables and exogenous variables.

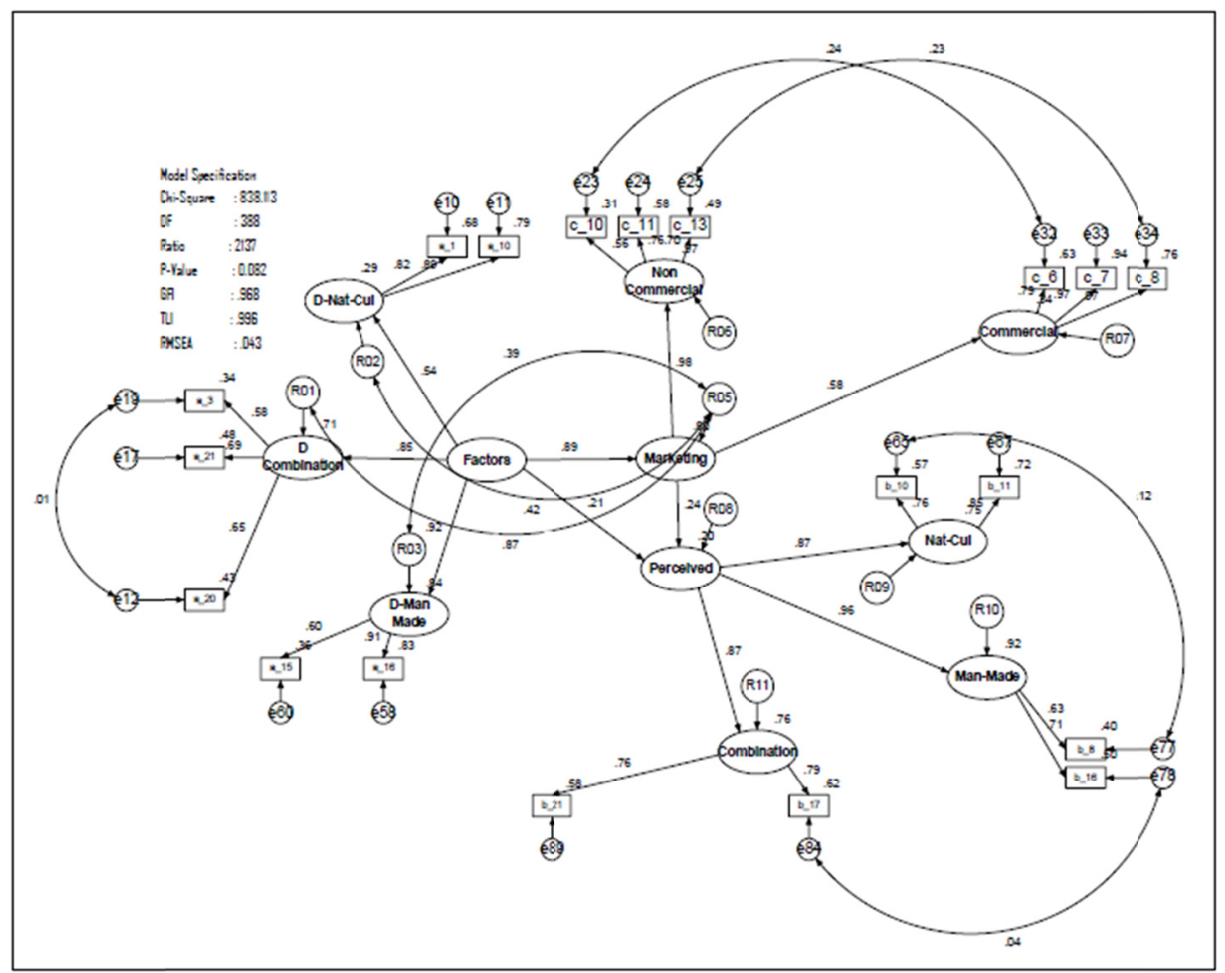

Figure 3. Re-specific model

Figure 3 illustrates the structure of model, the model suggests that interesting of history, delicious of cuisine, rich of culture, friendliness, transportation and cleanliness. SEM was performed to explain the relationships among these multiple variables (Hair et al., 2010). 
The study have been tested for all the fit criteria or indices of the structural equation model i.e. P-value $>0.05$; GFI $>0.9$; TLI $>0.9$ and RMSEA $<0.08$ (Bagozzi \& Yi, 1988; Anderson \& Gerbing, 1988; Byrne, 2001). All criteria including Cronbach's alpha values, factor loadings, path coefficients and goodness of fit indices used to measure the reliability and fit of the model were found to be highly satisfactory. Therefore, this study has confirmed choice factors, marketing environment and image perceived as valid dimension of Malaysian perception about Vietnam. It is thus further concluded that the hypothesized model proposed in this study fits the sample data adequately well and the finding of the study also suggest that all the research hypotheses are confirmed.

\section{Conclusions}

The empirical study tested a model to examine the image of Vietnam as a tourist's destination for Malaysian travelers. The results of CFA showed the beneficiary images of Vietnam as interesting history, rich culture, delicious cuisines and friendliness in which these beneficiary images should be maintained and improved. On the other hand, the negative images in Vietnam consists of poor transportation, poor infrastructure and cleanliness which imposes challenges to tourism industry of Vietnam should be given special attention for necessary rectification. Furthermore, the study suggests that there is strong effects of travel television, travel guidebook, brochure in promoting the images in Vietnam, thus, Vietnam should concentrate on promoting its images through these information sources. The results of the study also reveals that internet and words of mouth are among the most important sources of information for Malaysian tourists visiting Vietnam. Therefore, it is important to maximize this cost effective and efficient method in order to target the potential tourists. For instance, by using the effectiveness of internet as an effective tool to target those who had been to Vietnam in order to encourage them to return or share the holiday information with family or friends. Furthermore, internet is important tool to manage a location image and a tool to promote a destination, especially among the young generation travelers which was born in the new technology or information era and spent many hours on the virtual of world in order to looking for information, chatting, socializing and purchasing (Salamao et al., 2013). From the practical standpoint, there shall be efforts by offering the most suitable combination of local tourism service and products packages that support the above image to ensure the success of Vietnam destination marketing.

There were certain limitations of the study undertaken in which such limitations can be considered for future research. Firstly, the target population of the study is Malaysian travelers located mainly the major cities in West Malaysia i.e. Kuala Lumpur, Selangor, Penang, and Johor Bahru. Secondly, the promotion and marketing of Vietnam was mainly based on the secondary data, which available worldwide in the internet, books, documents, thesis, magazines and newspaper without any field studies and contacts with inside informants. Thirdly, the limitation of the study deals also with the lacking of data for both side Malaysia and Vietnam. Therefore, future research should be undertaken to examine the differences among the socio-demographic such as gender, age, or occupation and sub-group for those who had been to Vietnam and those who had not; to study the effect of information sources as an important aspect of destination image, to study on the relationship on textual information such as pictorial material and analysis of promotional material.

\section{References}

Anderson, J. C., \& Gerbing, D. W. (1988). Structural equation modeling in practice: a review and recommended two step approach. Psychological Bulletin, 102, 411-423. http://dx.doi.org/10.1037/0033-2909.103.3.411

Bagozzi, R. P., \& Youjae, Y. (1988). On the evaluation of structural equation models. Journal of the Academic of Marketing Science, 16, 74-94. http://dx.doi.org/10.1007/BF02723327

Baloglu, S., \& McCleary, K. W. (1999). A model of destination image formation. Annals of Tourism Research, 20(4), 868-897. http://dx.doi.org/10.1016/S0160-7383(99)00030-4

Blalock, H. M. Jr. (1982). Conceptualization and measurement in the social sciences. Beverly Hills, CA: Sage Publications.

Bollen, K. A. (1989). Structural equations with latent variables. New York: John Wiley \& Son (Asia) Pte Ltd. http://dx.doi.org/10.1002/9781118619179

Byrne, B. M. (2001). Structural equation modeling with AMOS: basic concept application and programming. Lawrence Erlbaum Associates.

Castro, B. C., Armario, E. M., \& Ruiz, D. M. (2007). The influence of market heterogeneity on the relationship between a destination's image and tourists future behaviour. Tourism Management, 28, 175-187. http://dx.doi.org/10.1016/j.tourman.2005.11.013 
Clark, J. T. (1969). The philosophy of science and the history of science. In M. Clayett (Ed.), Critical problems in the history of science (pp. 103-140). Madison, WI: University of Wisconsin Press.

Curran \& Bauer. (2010). Chapter 5: structure equation models with latent variables. Analytics, LLC.

Dann, G. (1996). Tourist images of a destination: An alternative analysis. Journal of Travel \& Tourism Marketing, 5(2), 41-55. http://dx.doi.org/10.1300/J073v05n01_04

Dodd, S. C. (1968). Systemmetrics for evaluating symbolic systems. Systemmatics, 6(1), 27-49.

Echtner, C. M., \& Ritchie, J. R. B. (1991). The meaning and measurement of destination image. The Journal of Tourism Studies, 2(2), 2.

Echtner, C. M., \& Ritchie, J. R. B. (1993). The measurement of destination image: An empirical assessment. Journal of Travel Research, 3-13. http://dx.doi.org/10.1177/004728759303100402

Echtner, C. M., \& Ritchie, J. R. B. (2003). The meaning and measurement of destination image. Journal of Tourism Studies, 14(1), 37-48.

Feigl, H. (1970). The orthodox view of theories: remarks in defense as well as critique. In M. Radnor \& S. Winokur (Eds.), Minnesota studies in the philosophy of science (p. 4). Minneapolis, MN: University of Minnesota Press.

Govers, R., F. M., \& Kumar, K. (2007). Virtual destination image: A new measurement approach. Annals of Tourism Research, 34(4), 977-997. http://dx.doi.org/10.1016/j.annals.2007.06.001

Grosspietsch, M. (2006). Perceived and projected images of Rwanda: visitor and international tour operator perspectives. Tourism Management, 27(2), 225-234. http://dx.doi.org/10.1016/j.tourman.2004.08.005

Gunn, C. (1972). Vacation scape: Designing Tourist Regions. Austin: Bureau of Business Research: University of Texas.

Hair, J., Anderson, R., Tatham, R., \& Black, W. (2010). Multivariate data analysis. Upper Saddle River, New Jersey: Prentice Hall.

Haque, A., \& Khan, A. H. (2013). Factors influencing of tourist loyalty: a study on tourist destination in Malaysia. In Proceeding of 3rd Asia-Pacific Business Research Conference (pp. 1-16). Kuala Lumpur, Malaysia: Faculty of Economics and Management Sciences, International Islamic University.

Hassan, A., \& Gulcin, B. T. (2013). Perceived image of Spain and Germany as a tourist destination for Dutch travelers. Journal of Economics, Business and Management, 1(1), 85-89.

Hempel, C. G. (1952). Fundamentals of concept of formation in empirical science. In international encyclopedia of unified science. University of Chicago Press. Chicago.

Hughes, M. A., Price, R. L., \& Marrs, D. W. (1986). Linking theory construction and theory: models with multiple indicators of latent variables. Academy of Management Review, 11(1), 128-144.

Jenkins, O. H. (1999). Understanding and measuring tourist destination images. International Journal of Tourism Research,

$1-15$. http://dx.doi.org/10.1002/(SICI)1522-1970(199901/02)1:1<1::AID-JTR143>3.0.CO;2-L

Jenkins, O. H., \& McArthur, S. (1996). Marketing protected areas. Australian Parks and Recreation, 32(4), 10-15.

Le, T. A. (2010). Marketing Vietnam's tourism to Japan: identifying and improving the images of Vietnam as a tourism destination for Japanese travelers. Ritsumeikan Asia Pacific, Japan.

Lin, C. T., \& Huang, Y. L. (2009). Mining tourist imagery to construct destination image position model. Expert Systems with Applications, 36, 2513-2514. http://dx.doi.org/10.1016/j.eswa.2008.01.074

Mao, Yue (Iris). (2008). Destination image building and its influence on destination preference and loyalty of Chinese tourists to Australia. The Hong Kong Polytechnic University.

Milman, A., \& Pizan, A. (1995). The role of aweraness and familiarity with a destination: The central Florida Case. Journal of Travel Research, 33(3), 21-27. http://dx.doi.org/10.1177/004728759503300304

Mohamad, M., Ali, A. M., Ghani, N. I. A., Abdullah, A. R., \& Mokhlis, S. (2013). Positioning Malaysia as a tourist destination based on destination loyalty. Canadian Center of Science and Education, 9(1), 286-292.

Nunnally, Y. J. C., \& Bernstein, J. H. (1994). Psychometric theory (3rd ed.). New York: McGraw-Hill.

O'Leary, S., \& Deegan, J. (2003). People, pace, place: qualitative and quantitative images of Ireland as a tourism 
destination in France. Journal of Vacation Marketing, 9(3), 213-226. http://dx.doi.org/10.1177/135676670300900302

Pearce, P. L. (1982). Perceived changes in holiday destinations. Annals of Tourism Research, 9, 145-164. http://dx.doi.org/10.1016/0160-7383(82)90044-5

Phelps, A. (1986). Holiday destination image-The problem of assessment: an example developed in Menora. Tourism Management. http://dx.doi.org/10.1016/0261-5177(86)90003-8

Prebensen, N. K. (2007). Exploring tourists' images of a distant destination. Tourism Management, 28(3), 747-756. http://dx.doi.org/10.1016/j.tourman.2006.05.005

Reilly, M. D. (1990). Free elicitation of descriptive adjectives for tourism image assessment. Journal of Travel Research, 28(4), 21-26. http://dx.doi.org/10.1177/004728759002800405

Reynolds, W. H. (1965). The role of the consumer in image building. California Management Review, 69-76. http://dx.doi.org/10.2307/41165634

Salem, S. H. (2009). An evaluation of the image of the Hashemite Kingdom of Jordan in the British and Swedish markets and the implications for marketing the country as a tourism destination. Bournemouth University.

Salleh, M., Omar, K., \& Yaakop, A. Y. (2013). Tourist satisfaction in Malaysia. International Journal of Business and Social Science, 4(5), 221-226.

Salomao, A. F., Edvan, C. A., Michelle, H. K., \& Francisco, V. S. M. (2013). Destination image on the web: evaluation of pernambuco's official tourism destination websites. Business Mangement Dynamics, 2(10), 3548.

Seehyung, K. (2005). A causal model of linkages between environment and organizational structure, and its performance implications in international service distribution: an empirical study of restaurant and hotel industry. (Unpublished PhD. Disseration). Virginia Polytechnic Institute and State University, Blacksburg, Virginia.

Stepchenkova, S., \& Eales, J. S. (2010). Destination image as quantified Media messages: The effect of news on tourism demand. Journal of Travel Research, 50(2), 198-212. http://dx.doi.org/10.1177/0047287510362780

Stepchenkova, S., \& Morrison, A. M. (2006). The destination image of Russia: From the online induced perspective. Tourism Management, 27(5), 943-956. http://dx.doi.org/10.1016/j.tourman.2005.10.021

Stepchenkova, S., \& Morrison, A. M. (2008). Russia's destination image among American pleasure travelers: Revisiting Echtner and Ritchie. Tourism Management, 29(3), 548-560. http://dx.doi.org/10.1016/j.tourman.2007.06.003

Tasci, A. D., \& Gartner, W. C. (2007). Destination image and its functional relationships. Journal of Travel Research, 45(4), 413-425. http://dx.doi.org/10.1177/0047287507299569

UNWTO. (2011). UNWTO Tourism Highlights, 2011 Edition. Facts \& Figures. Retrieved from http://mkt.unwto.org/sites/all/files/docpdf/unwtohighlights11enlr_1.pdf

Vaughan, R. D. (2007). Images of Romania as a potential holiday destination. International Journal of Tourism Policy, 1(1), 1-16. http://dx.doi.org/10.1504/IJTP.2007.013894

Vaughan, R. D., \& Edwards, J. R. (1999). Experiential perceptions of two winter sun destinations: The Algarve and Cyprus. Journal of Vacation Marketing, 5(4), 356-368. http://dx.doi.org/10.1177/135676679900500405

Veal, A. J. (2006). Research methods for leisure and tourism: a practical guide (3rd ed.). Edinburgh: Financial Times/Prentice Hall.

Vietnam Administration of Tourism. (2014). International visitors to Vietnam in September and 9 months of 2014. VNAT. Retrieved from http://www.vietnamtourism.com/en/index.php/news/items/8432

Vietnam Travel. (2009). Vietnam Tourism Statistic. Vietnam Travel. Retrieved from http://www.vietnamtravel.org/vietnam-tourism-statistics

Vietnamnet. (2013). Tourism is a key economic sector of the Red River Delta. Retrieved from http://www.vietnamtourism.gov.vn/english/index.php?cat $=0105 \&$ itemid $=6795$

VNAT. (2014). International visitor to Vietnam. Vietnam National Administration of Tourism. Retrieved from http://www.vietnamtourism.com/en/index.php/news/items/7691

$\mathrm{Vu}$ The Binh. (2013). Vietnam looks to sharpen tourism image. Vietnam Investment Review. Retrieved from 
http://www.vir.com.vn/news/en/travel/vietnam-looks-to-sharpen-tourism-image.html

Woodside, A. G., \& Lysonski, S. (1989). A general model of traveler destination choice. Journal of Travel Research. http://dx.doi.org/10.1177/004728758902700402

\section{Copyrights}

Copyright for this article is retained by the author(s), with first publication rights granted to the journal.

This is an open-access article distributed under the terms and conditions of the Creative Commons Attribution license (http://creativecommons.org/licenses/by/3.0/). 